\title{
From Media Events to Expressive Events : An Interview with Daniel Dayan
}

\section{Sumiala, Johanna Maaria}

2018-02

Sumiala , J M , Valaskivi , K \& Dayan , D 2018 , ' From Media Events to Expressive Events :

An Interview with Daniel Dayan ' , Television \& New Media , vol. 19 , no. 2 , pp. 177-187 . https://doi.org/10.1177/152

http://hdl.handle.net/10138/310838

https://doi.org/10.1177/1527476417741673

unspecified

acceptedVersion

Downloaded from Helda, University of Helsinki institutional repository.

This is an electronic reprint of the original article.

This reprint may differ from the original in pagination and typographic detail.

Please cite the original version. 


\section{From Media Events to Expressive Events}

Television \& New Media

I-11

(C) The Author(s) 2017

Reprints and permissions: sagepub.com/journalsPermissions.nav DOI: $10.1|77 / 15274764| 7741673$ journals.sagepub.com/home/tvn

(SAGE

\title{
Johanna Maaria Sumiala', Katja Valaskivi², and Daniel Dayan ${ }^{3}$
}

\begin{abstract}
In this interview, Professor Daniel Dayan provides a philosophical and theoretical reflection on the development of media event theory and its influence in media and communication studies since 1990s. He reveals the main theoretical premises and inspirations behind the theory and provides a thoughtful reflection of the historical situation in which the theory was developed. The latter part of the interview observes the present day terrorist violence in the framework of media event theory.
\end{abstract}

\section{Keywords}

media events terrorism, media rituals, expressive events, news media, terror

The interview was conducted via email.

Johanna Sumiala and Katja Valaskivi (JS/KV): Could you tell us about the time and context when and where the theory of the media event began to form?

Daniel Dayan (DD): The project started at the Hebrew University in Jerusalem, at the newly created Communications Institute, where I had just been appointed. Elihu Katz had invited me to teach semiotics while I was fresh from Stanford University and still completing my doctoral dissertation for Roland Barthes. The announcement of the visit of President Anwar Sadat to Jerusalem elicited an unprecedented explosion of hope, taking everybody by surprise. Elihu had an interesting idea of covering the unraveling event day by day like journalists? Every evening we would give a press conference to an audience of local correspondents and members of the world press. I was challenged to demonstrate that my semiotic approach would make sense to

\footnotetext{
'University of Helsinki, Finland

${ }^{2}$ Tampereen Yliopisto, Finland

${ }^{3}$ Ecole des Hautes Etudes en Sciences Sociales, Paris, France

Corresponding Author:

Johanna Maaria Sumiala, University of Helsinki, P.O. Box 54, Helsinki, 000I4, Finland.

Email: johanna.sumiala@helsinki.fi
} 
hard-boiled reporters. I bravely accepted, and the press conferences started. In the process, we realized that the event we were attending did not really belong in the genre of news. It was almost news, but it was also something else. We began looking for other events that would help us find out what this "something else" was.

JS/KV: What were your main sources of intellectual inspiration in bringing the ideas of "event" and "media" into theoretical interplay?

DD: Our first source was obvious. The institution of news constantly brings the ideas of event and media together. But we were explorers of an emerging country in what James Carey (1986) defined as the dark "continent of journalism." Elihu Katz's sources of inspiration included the Durkheimian tradition, and in particular Edward Shils and Michael Young's (1953) The Meaning of Coronation. It also included a famous paper by Kurt Lang and Gladys Engel Lang (1953) on the triumphal visit of General Mac Arthur to Chicago. Yet I believe that, first of all, Elihu's inspiration came from his own work with Paul Lazarsfeld. In fact, our book would demonstrate that, paradoxically, the "two step flow of communications" was by no means incompatible with the possibility of powerful effects. My own inspiration came from my training in semiotics and anthropology, and from a renewed interest for events in France, after decades of undisputed reign of the Annales school of history.

Before Annales, events provided intellectual tools, explanatory devices, instruments for articulating temporalities. Events were a way of thinking about continuity, discontinuity, beginning, origin, and causality. The Annales school banned their study and promoted instead that of long-lasting structures. But, interestingly, our project coincided with the Annales' decision to return to the study of events. After years of structuralism, French social scientists were rediscovering the importance of events. Sociologists, such as Edgar Morin; textual analysts, such as Roland Barthes; and psychoanalysts who debated the reality of traumatic fantasies shared this renewed interest in events. Paul Ricœur (1992) commented on this turn in his essay Le retour de l'Événement. Events came back to the fore, but they were now analyzed as texts-like childhood, sexuality, punishment, or surveillance, events - were to be discussed as configurations that typified a given period. In his 1869 preface to War \& Peace, Tolstoy put it succinctly, "The historian is concerned with the outcome of an event. The artist is concerned with the event itself." In that sense, our post-Annales inspiration largely came from those Tolstoy calls "artists." We were of course preoccupied with the causes and consequences of events, but we were mainly concerned with the "events themselves." We felt that the form of events deserved specific attention.

JS/KV: How would you reflect on the strengths of the theory at the time?

DD: I would like to list five strong points and two weaker ones.

First, our study relocated the question of reception out of the domestic context and into the public sphere. Media events offered the possibility of looking at modes of reception that were in themselves public performances. Even the home became a public space. Our audiences were publics that made themselves visible, performing publics, dramaturgic publics. Observing them meant noticing how deliberately they calculated their self-presentations. Second, our study directed the reader to an anthropology of public attention. In a different context, we were asking a question that Clifford Geertz 
(1973) had raised about Balinese cockfights: What made certain occasions into "deep play," as opposed to shallow play? Why did they attract so much attention? Why were media events perceived as so much more important than daily news?

Third, our study illustrated the existence of a liminal or antistructural form of television, and the existence of a liminal or antistructural style of reception. Inspired by Victor Turner, the study of these liminal forms presented the advantage of illuminating by contrast everyday forms of television.

Fourth, our study highlighted the performative nature of media rituals. Following John Langshaw Austin, we asked the question, "What makes an event felicitous?" And using Claude Levi Strauss' notion of symbolic efficacy, we stressed the potentially momentous consequences of transforming the narratives through which we perceive history. In Ricœur's (1984) words, such narrative transformations were a mode of "prefigurating, configurating, or reconfigurating" societies. We were clearly enlarging the usual definitions of media effects.

Last but not least, our study gave a sense of a zeitgeist. The events we studied occurred when the Cold War was ending, but before terrorism came to the fore as the major provider of television events. Thus, we were in fact depicting a period in which the most significant events were not expressions of anger or displays of violence, but manifestations of hope. Our strength was in accounting for this hopeful dimension, in noticing what was really original in this irenic parenthesis. Our book feels amazingly optimistic in retrospect.

One of the weaker points of our theory is that we omitted the issue of counter-narratives, which was astonishing for an approach that was centered around narratives. Plus, our definition of media events was too narrow. Speaking of "media events" created an expectation that we would discuss all media and all events. In fact, we only discussed certain kinds of events (consensual events and ceremonial events) and only one medium (network television). Of course, we carefully specified the existence of subgenres of media events such as "contests," "conquests," and "coronations." Yet we failed to define the limits between our genre as a whole and other similar genres. We failed at comparing our events to many other media dramaturgies that rely on visibility and exemplarity. We failed at discussing media events within a corpus of "expressive events," such as conflictual events, pseudo-events, terrorism, and so on.

JS/KV: What do you think of the later developments of media event theory, namely, in relation to the idea of disruptive media events and their social functions?

DD: I noticed two sorts of late developments in media event theory. The first were re-readings, reinterpretations, revisions coming from cultural studies or critical theory. In the second case, there were empirically oriented discussions of recent transformations affecting the genre of media events and neighboring genres, in a perspective inspired by mediology, Friedrich Kittler or Jacques Derrida. I will address them separately.

After 9/11, both Elihu Katz and myself independently felt that certain types of integrative or consensual media events were somehow losing their power to attract the world's attention. Violent, conflictual events were taking over. Yet, as we were told by Nick Couldry and Andreas Hepp (2010, 2017), the conflictual events we saw as the new dominant events had been there all along. It was our integrative perspective that 
had been blinding us to their conflictual dimension. It was not the nature of events that had changed but our refusal to assess their true character. Thus, according to this critique, consensual events were nothing but agonistic events with a consensual mask.

In response, I would say that the consensual dimension that we stressed was not a mirage. It was indeed there. Treating it now as a mere lure involves the danger of rewriting history. For example, today, we know that the peace process proposed by Anwar el Sadat failed. Should it retrospectively be dismissed as a decoy or a trap? And for whom? And why should suspicion toward this visit be more enlightening than taking it at face value?

What Ricœur called the "hermeneutics of suspicion," that is "the circumventing of obvious or self-evident meanings in order to draw out less visible and less flattering truths does not always lead to higher forms of understanding. Durkheimian theory is typically accused of being the mere recitation of a dogma, some sort of a cult celebrating a Goddess called "Society." Are things any different with the hermeneutics of suspicion? Could we not see the latter as the same dogma in reverse? As a cult celebrating the absolute supremacy of the gods of "Conflict?" Both integration theory and critical theory have the virtue and the defect of being unfalsifiable. Analysts, thus, find themselves in the situation of having to choose between two symmetrical dogmatisms, between Scylla and Charybdis.

A solution to this dilemma might consist of using one dogma against the other, of accepting the fact that each dogma delivers part of the solution. Such is perhaps the meaning of Steven Lukes' (1975) retreat from critical dogmatism. Proposing a much broader definition of "power" than the one he started with, Lukes speaks not only of power as "power over," but he also discusses power as the "power to." Applied to our media events, Lukes' reformulation means that consensual events allow certain groups to exert "power over" other groups, but that they are also endowed with the "power to" bring together various groups in a society. Of course, consensual events tend to emphasize specific versions of solidarity, and consequently promote the interests of given groups at the expense of others. Of course, certain versions of solidarity are akin to Walter Benjamin's $(1968,254,256)$ "history of the victors." Yet the solidarity they bring about cannot simply be pushed aside as a nefarious illusion. Could any society survive without a minimal amount of solidarity? Without what Jeffrey Goldfarb (1998) calls civility? Our media events have often served as a barometer of this sort of civility. If you doubt it, look at what happened to presidential debates in the time of Donald Trump.

Returning to the second development in media event theory, we knew that by concentrating on a type of event that was emblematic of the end of the twentieth century, we were contributing to a history of forms. Such a history is more relevant now than ever, since events are changing shape again, morphing from a broadcast mode to a digital mode. Our conception of media events fits in the broadcast mode, as a theatrical form with a strong focus, unified perspective, deliberate scripting, and an almost initiatic temporality. In the digital mode, multiple feeds lead to labyrinthine structures and a diversity of foci. The distinction between sacred time and profane time is reversible. News can become media events and vice versa. Emplotment is replaced by a maze of "assemblages" and "distributed configurations" (Frosh and Pinchevski 2017). 
Finally, broadcast media events do not merely differ from the forms that replaced them. In a way, they generated these forms. While the character of media events as timeouts from the everyday made them clearly distinctive, media events may also have functioned as a laboratory, where an updated language was being invented. Thus, many formal characteristics of today's news come from media events. Think of the way in which certain privileged news benefit from a quasi-monopoly on public attention; of their unfolding in every direction at the expense of lesser news (now relegated to the bottom of TV screens); of their use of the "live" format to offer a collective experience, instead of a mere account of incidents. The resulting stories end up being neither news nor the media events that we used to know. Media events have stopped occurring by appointment. Their status no longer needs to be decided in advance. Technologies of recording and broadcasting are supple enough to allow improvising a media event whenever desired.

JS/KV: What kind of modifications would you see necessary in the contemporary media environment?

DD: Being especially interested in information, I am often astonished by the conditions through which it is delivered. Today, information is lost in the middle of a galaxy of surrounding genres, many of which verge on the fictional, and thus dispense with any need for accountability. I would like such genres, what I would call "peri-information," to be kept clearly distinct from actual information. I also would like to be able to identify the actual origin of statements that are offered as a "vox populi." A recurrent use of indirect style tends to sever the thread connecting utterances to their actual sources, forcing us to wonder: who is actually speaking? Whose voice do we hear? Who is the "author" or "principal" of the uttered words (Goffman 1981)? The practice of journalism is in dire need of a specific theory of citation and intertextuality. But how does one imagine such a thing as visual quote marks?

JS/KV: In your view, what are the implications of globalization for the theory?

DD: First, I think that globalization should be put in the plural. History is a long string of globalizations. As shown by the Annales scholars and Fernand Braudel's (1967) concept of economies-that-are-worlds (économies-mondes). I'll limit myself to two remarks. One deals with attention, the other with gift economies.

We are witnessing today a new form of globalization, the globalization of attention, which signifies the possibility of focusing simultaneously — or almost simultaneouslyon the same events all over the world. This globalization of attention raises a number of questions: What are the events that benefit from it? Whose events are they? How do they get such a privilege? Whose events are left out? Our book on media events was an attempt at answering such questions. But our book described consensual events in an era of centered attention. Attention is now dispersed. What is called the global scene is in fact a multiple scene, a world-size three-ring circus. Big broadcasting organizations are still among the main actors in the circus. They produce their respective brands of international news, and, of course, the occasional media event. But national groups or polities that have no such media organizations at their disposal manage nevertheless to be present on the international scene. These weaker actors rely on digital media to produce their own events, for example, terror events. Then, they count on viral propagation and on adoption by one of the big media organizations to achieve their own sort of ubiquity. 
But there is another aspect to globalization: groups of nations from convivial circles, sometimes reminiscent of the ceremonial exchange system that Malinowski (1922) observed in the Trobriand Islands and described as a "Kula ring." Thus, Media Events may be seen as a ceremonial currency and an invitation at sharing a common global project. Drawing a map of where events occur, one notes that their sites keep changing. Depending on the event, some members of groups of nations step on stage; others constitute the audience. For any given nation, to host a media event is a sign of recognition. Some do not even try. Thus, for a long time, South Africa was the "pariah" of the democratic community (Evans 2017). At one point, it hosted a string of Media Events

That such events were picked up internationally was a major form of recognition. South Africa could now serve as the emblem of a "common center."

Such exercises in globalism also concern events that are conflictual. Thus, when French state television treated in media event style (albeit without the "live" dimension) the alleged shooting in cold blood of a Palestinian boy and his father by Israeli soldiers, the resulting video was sent free of charge to about sixty countries who were invited to join in condemnation. This visual gift served to strengthen ties within a given community of nations.

While expressive events are independent from each other, and while each one of them is unique, the fact of situating them in a global context allows us to note that they relate to each other not simply as examples of the same genre, but as tokens within distinct rings of global exchange. Media events talk to other media events. Terror events also talk to other terror events, but within a model that is no longer that of a "Kula ring." This model rather approximates the practice of "Potlatch." Of course, the two models have many points in common. Both illustrate Marcel Mauss' $(1925,50)$ theory of "the gift," and differ from market economies by offering lavish displays of generosity. In Kula rings, the dimension of generosity predominates, and the exchange of gifts strengthens political ties between the inhabitants of different islands. In Potlatch rituals (described by Franz Boas in British Columbia), a dimension of challenge predominates. Offerings done during Potlatch ceremonies allow participants renegotiating their status, but the gift making is sometimes so agonistic as to verge on a form of war. Both Potlatch and Kula rings are modes of insuring social cohesion. Yet, while structurally similar, these "prestige economies" powerfully differ by their tonality, and this also applies to their television counterparts.

JS/KV: What about terror events?

DD: Terror events used to be co-productions with terrorist organizations as directors, and media organizations as cameramen, editors, and commentators. Terror events are now delivered ready-made, or, to be precise, ready for re-diffusion.

The evolution of terror has invited many theoretical explorations. Two seem particularly promising. The first has been about the ethical dimension of conferring visibility. The second has been about the emotions expressed by media events in different contexts and at different times.

First, in terms of the ethical dimension of conferring visibility, I would note an important book, Media and Morality, in which Roger Silverstone (2006) discusses the responsibilities of the media in conferring visibility on those he defines as "others." In 
my own vocabulary, I would say that Silverstone discusses the media as institutions of display" or "monstration." His point is to assess the moral distance required for a respectful display, one that does not turn the other into a "monster." The context of globalization makes Silverstone's question crucial.

Yet, For Silverstone, "otherness" is exemplified by the extreme case of the terrorist, whose voice and words deserve hospitality on our television screens. I am embarrassed at Silverstone's privilege given to the terrorist. Of course, our relationship to all others is the definition of ethics. But choices have to be made. Globalization offers us a vast range of potential "others," but there is a limited amount of attention. Thus, deciding who is "the other" is often a political question. This question means in fact: Who should be the other? Who do I choose as the other? Who deserves to be the other?

Thus, it took six months of genocide in Rwanda for the French press to consider the possibility that Tutsis could be our "others," and that their ongoing massacre had to be covered. Fetishizing some "others" as embodiments of otherness can only be done at the expense of those others that are not fetishized, and whose fate is met in general indifference. In other words, I mean to pursue the ethical exploration started by Silverstone, yet I am fully aware that the notion of "others" involves in fact two sorts of others; those we consider and those we dismiss. Do we really need a "morality" for which only the most violent others qualify as worthy of our ethical attention?

The second avenue I would explore concerns the tonality of expressive events. Terror events today, and especially those that emanate from the Muslim/Arab world, are characterized by a complex of emotions in which humiliation plays a major role. Humiliation, surrounded by anger and resentment, is explicitly what drives terrorists to act.

Major expressive events of the Western world, on the other hand, have long been characterized by a sense of hope. Hope was emblematic of what Elihu Katz and myself called media events. Hope was present in what we called "coronations" and was at the heart of our "conquests," from the visit of Sadat to the Moonlanding. Today, hope is no longer the West's dominant emotion. As diagnosed by Dominique Moïsi (2008), hope has been replaced by fear. It is fear that organizes the closing of borders and the construction of physical and administrative walls. Of course, there are still some hopeful media events today, but such events typically celebrate great expectations of the past. For example, South Africa's funeral for Nelson Mandela was a re-enactment of a time when Mandela meant the birth of a new South Africa. Hope is being replaced by nostalgia for a time when there was hope.

JS/KV: Based on your later work La terreur spectacle: Terrorisme et télévision (Dayan 2006) on violence and terror in the media, how would you analyze the Charlie Hebdo attacks in 2015 in Paris? We ask based on our own work on this case study (Sumiala et al., 2018). ${ }^{1}$

DD: My recent work discusses the actual construction and narrative reconstruction of events in terms of news dramaturgies. Such dramaturgies are both interpretive elucidations and forms of action endowed with the performative power of defining situations. I would like to discuss such dramaturgies in a brief sequence modelled on the cinematographic pattern of shot and reverse-shot. 
On the one hand, dramaturgies are staged by terrorist organizations, as part of their strategies of visibility. Of course, I am well aware that such strategies are often individual, and that the "organizations" that sponsor them are not much more than a franchise used by these isolated individuals for what amounts to "one-man-shows." On the other hand, I wish to look at the specific, and sometimes unexpected, responses elaborated by societies that are exposed to terror, and, in particular, at the explosive encounter of their collective stress with agenda-setting media.

For a long time, terror dramaturgies relied on a model of the-terrorist-as-an ambassador who acted in the name of helpless victims, of the terrorist as the self-appointed advocate of suffering groups. This model was meant to trigger compassionate responses. Western publics were invited to forget about violence that was unfortunate but necessary, and to treat terrorism as a particularly intense form of rhetorical emphasis. These publics were called to focus on "distant sufferings" within a frame beautifully sketched by Luc Boltanski (2004). Massacres were an act of protest. Terrorist violence was a call for compassion.

9/11 marked the moment in which this model was abandoned. Another model replaced it. The new dramaturgy was one of crime and punishment. In this model, the West was cast as the equivalent of Sodom and Gomorrah. Terrorists were given the role of exterminating angels. Speaking no longer in the name of suffering, terrorists spoke in the name of God. This dramaturgy culminated with a string of executions that started, even before Daesh, with the beheading of Daniel Pearl in 2002. The overall frame of this dramaturgy was no longer inspired by Boltanski's "distant suffering," but by Giorgio Agamben's (1998) Homo sacer. Eliminating the "wrong" humans was no longer a homicide.

Let me now turn to the "target" societies. The same event can give birth to many narrative constructions. Take a terrorist action. It initially takes the form of a triggering incident and generally ends up as a series of collective performances (such as demonstrations). These collective performances not only respond to the brutality of the incident but also underline the incident's import. They provide the validation this incident requires to become an "event."

Yet are such collective performances part of the event or merely its aftermath? And is the triggering incident part of the event, or merely its prelude? What one chooses to frame as the event involves in fact an ideological form of agenda setting. To anti-terrorists, a terror act is the real event. To those who, without openly supporting terrorism, call themselves "anti-anti" (i.e., those who oppose anti-terrorism), antiterrorist actions and demonstrations can sometimes become the only realities that count.

After the attacks on the Atocha station in Madrid in 2004, the major issue on the media agenda was not terror, but why prime minister José María Aznar had mentioned the separatist Basque group ETA (Euskadi Ta Askatasuna) among the possible culprits or accomplices. The same displacement of attention from the massacres themselves occurred in France after the attacks of January 7, 8, and 9 in 2015. Certain commentators chose to ignore the attacks, and to focus public attention on the mass demonstrations of January 11 . They did so by attacking the crowds who had expressed solidarity with the slain journalists. These crowds were carrying posters saying "Je suis Charlie" ("I am Charlie"). In a pamphlet published under the title Qui est Charlie? ("Who is Charlie?"), the demographer Emmanuel Todd (2016) questioned 
the motives of the demonstrators and described the demonstrations themselves as a form of religious crusading. According to Julien Coupat (L'Obs, May 13, 2015), ${ }^{2}$ terrorism was nothing but a pretext "for an obscene and totalitarian control of the population." Terrorism was, in other words, nothing but a lame alibi for a collective performance that combined collective hysteria with attacks on civil liberties. France was in a "state of siege," and the demonstrations were part of an ongoing "war of civilizations" (Coupat 2015).

Ignoring the terrorist actions themselves was dictated by a dogma according to which terrorism simply does not exist as a form of action for which, for example, the terrorists could be held accountable. Terrorism is nothing but a response. It exclusively belongs to the realm of reaction. Thus, discussing terrorism can only mean discussing the causes of terrorism. Once this dogma is accepted, a second decision follows. If there are no terrorist actions, then responses to terrorism can hardly be seen as reactions. They must be upgraded and seen as full-fledged initiatives. In the absence of terrorism, they become the only actions worth discussing. At this point, all the narrative choices I have been discussing converge. Through a narrative form of agenda setting, ideological commitments have dictated the nature of the considered event. They have proceeded to its reconstruction.

Of course proceeding to a reconstruction is not exclusive to Emmanuel Todd or Julien Coupat. The narratives offered by these commentators are meant as a challenge to other, mainstream, narratives. Newspapers readers and television spectators have only access to "interpretations" of the event, and of course all these interpretations are attempting to become performative.

Does this means that all narratives are equal?

Not at all, as pointed by Ricoeur (1970) and by all those who have studied the art of translation, interpretations can be more or less adequate, more or less exhaustive, more or less faithful to the situation they stand for. The narrative I chose to stress here was one in which omissions were particularly blatant due to the decision to "see through" terrorism and thus to discuss terrorism without terrorism. Yet it was one among many. And I see the task of the critic as one of protesting this, and other, obfuscations. ${ }^{3}$

\section{Declaration of Conflicting Interests}

The authors declared no potential conflicts of interest with respect to the research, authorship, and/or publication of this article.

\section{Funding}

The authors received no financial support for the research, authorship, and/or publication of this article.

\section{Notes}

1. The framework I developed in La Terreur Spectacle (Dayan 2006) was extended in the paper Beyond Media Events: Disenchantment, Derailment, Disruption (Dayan 2010). It was further extended in an interview with Philippe Raynaud in May 2015 (Les médias dans la mêlée, Paris: INA Global), and in an interview with Daniel Schneidermann in March 2016: (Arrêt sur Images). 
2. Retrieved from http://tempsreel.nouvelobs.com/loi-renseignement/20150511.OBS8735/ exclusif-julien-coupat-le-cynisme-de-nos-gouvernants-est-inoxydable.html

3. I have been inspired, as always, by an ongoing discussion with my friends Elihu Katz and Jeffrey Goldfarb. I should also mention a special issue of Media, Culture \& Society (Special Section: Media Events, 2017). Many of my points were inspired by the challenging essays of Nick Couldry, Martha Evans, Paul Frosh, Jeff Goldfarb, Andrea Hepp, ChinChuan Lee, Hongtao Li, Amit Pinchevski, Paddy Scannell, Julia Sonnevend, and Espen Ytreberg.

\section{References}

Agamben, Giorgio. 1998. Homo Sacer: Sovereign Power and Bare Life. Stanford: Stanford University Press.

Benjamin, Walter. 1968. "Theses on the Philosophy of History." In Illuminations edited with an introduction by Hannah Arendt, translated by Harry Zohn. New York: Schocken Books.

Boltanski, Luc. 2004. Distant Suffering: Morality, Media and Politics. Cambridge: Cambridge University Press.

Braudel, Fernand. 1967. Civilisation matérielle, économie et capitalisme (XVe-XVIIIe siècle): Le possible et l'impossible: les homes face à leur vie quotidienne [Civilization and Capitalism, 15th-18th Century, Vol. 1-111]. Paris: Armand Colin.

Carey, James. 1986. "The Dark Continent of American Journalism.” In Reading the News, edited by Michael Schudson and Robert Manoff, 146-96. New York: Pantheon Books.

Couldry, Nick, and Andreas Hepp. 2017. "The Continuing Lure of the Mediated Centre in Times of Deep Mediatization: 'Media Events' and Its Enduring Legacy.” Media, Culture \& Society. Published electronically August 18. doi:10.1177/0163443717726009.

Couldry, Nick, Andreas Hepp, and Friedrich Krotz. 2010. Media Events in a Global Age. 23-31. Abingdon: Routledge.

Dayan, Daniel. 2006. La terreur spectacle: Terrorisme et television [The terror spectacle: Terrorism and television]. Paris: INA and De Boeck.

Dayan, Daniel. 2010. "Beyond Media Events: Disenchantment, Derailment, Disruption." In Media Events in a Global Age, edited by Nick Couldry, Andreas Hepp, and Friedrich Krotz, 23-42. Abingdon: Routledge.

Evans, Martha. 2017. "Media Events in Contexts of Transition: The South African Case." Media, Culture \& Society. Published electronically. August 18. doi: 10.1177/0163443717726012

Frosh, Paul, and Amit Pinchevski. 2017. "Media and Events after 'Media Events."' Media, Culture \& Society. Published electronically. August 18. doi: 10.1177/0163443717726007

Geertz, Clifford. 1973. The Interpretation of Cultures: Selected Essays. New York: Basic Books.

Goffman, Erving. 1981. Forms of Talk. Philadelphia: University of Pennsylvania.

Goldfarb, Jeffrey C. 1998. Civility and Subversion: The Intellectual in Democratic Society. Cambridge: Cambridge University Press.

Lang, Kurt, and Gladys Engel Lang. 1953. "The Unique Perspective of Television and Its Effect: A Pilot Study." American Sociological Review 18 (1): 3-12.

Lukes, Steven. 1975. Émile Durkheim: His Life and Work: A Historical and Critical Study. Harmondsworth: Penguin.

Malinowski, Bronislaw. 1922. Argonauts of the Western Pacific: An Account of Native Enterprise and Adventure in the Archipelagoes of Melanesian New Guinea. London: Routledge \& Sons. 
Mauss, Marcel. 1925. 1950. \& seq. Essai sur le don. Forme et raison de l'échange dans le sociétés archaïques [The Gift: The Form and Reason for Exchange in Archaic Societies]. Paris: Presses Universitaires de France. English translations: Cohen \& West (1954) Routledge (2002).

Moïsi, Dominique. 2008. La Geopolitique de l'émotion: Comment les cultures de peur, d'humiliation et d'éspoir façonnent le monde [The Geopolitics of Emotion: How Cultures of Fear, Humiliation and Hope Shape the World]. Paris: Flammarion.

Ricoeur, Paul. 1970. Freud and Philosophy: An Essay on Interpretation. Translated by Denis Savage. New Haven: Yale University Press.

Ricœur, Paul. 1984. Time and Narrative, Volume 1. Translated by Kathleen McLaughlin and David Pellauer. Chicago: University of Chicago Press.

Ricœur, Paul. 1992. "Le retour de l’Événement." Mélanges de l'Ecole Française de Rome [The return of the Event: Mixtures of the French School of Rome]. Italie et Méditerranée 104 (1): 29-35.

Shils, Edward, and Michael Young. 1953. "The Meaning of Coronation." The Sociological Review 1 (2): 63-81.

Silverstone, Roger. 2006. Media and Morality: On the Rise of the Mediapolis. Cambridge: Polity Press.

Sumiala, Johanna, Katja Valaskivi, Minttu Tikka, and Jukka Huhtamäki (2018). Forthcoming. Hybrid Media Event: Charlie Hebdo Attacks and the Global Circulation of Violence. Bingley: Emerald Group.

Todd, Emmanuel. 2016. Qui est Charlie? Sociologie d'une crise religieuse [Who is Charlie?: Xenophbia and the New Middle Class]. Paris: Seuil.

Tolstoy, Leo. 1869. Preface to War and Peace. French translation. Translated from French by the author. Lausanne: Editions Rencontre, 1961.

\section{Author Biographies}

Johanna Maaria Sumiala is a professor in Media and Communication Studies, University of Helsinki. She is an expert in the fields of media sociology and media anthropology, digital ethnography and visual culture. She has recently published articles on mediatized violence and ritualized (online) communication and she is co-author of the book Hybrid Media Events. The Charlie Hebdo Attacks and Global Circulation of Terrorist Violence together with Katja Valaskivi, Minttu Tikka and Jukka Huhtamäki to be published with Emerald in 2018.

Katja Valaskivi (University of Tampere) is vice dean and the research director in Tampere Research Centre for Journalism, Media and Communication (COMET). She is a media scholar, who has published widely in the issues of media and the nation, nation branding, media and social theory, and circulation in media society. The title of her most recent single-authored book is Cool Nations: Media and the Social Imaginary of the Branded Country (Routledge 2016).

Daniel Dayan is a former director of Research in Sociology, at Centre National de la Recherche Scientifique, professor of Media Theory at the Institut d'Etudes Politiques (Sciences-po), Paris, and a Hans Speier visiting professor at the New School of Social Research in New York. He holds degrees in anthropology, comparative literature, semiotics and film studies from the Sorbonne, Stanford University and L'Ecole des Hautes Etudes en Sciences Sociales where he received a $\mathrm{PhD}$ in aesthetics under the direction of Roland Barthes. He has published widely in French and English. One of his most seminal works is Media Events: The Live Broadcasting of History published in 1992 by Harvard University Press together with Elihu Katz. 